v.9, n.2

Vitória-ES, Apr.-Jun. 2012

p. 26-46 ISSN 1808-2386 DOI:http://dx.doi.org/10.15728/bbr.2012.9.2.2

Student loyalty based on relationship quality: an analysis on higher education institutions

Fábio Vinicius de Macedo Bergamo

Adventist School of Bahia

Antonio Carlos Giuliani

Methodist University of Piracicaba - UNIMEP

Silvia Helena Carvalho Ramos Valladão de Camargo

Methodist University of Piracicaba - UNIMEP

Felipe Zambaldi ${ }^{\ddagger}$

Getúlio Vargas Foudation - FGV/EAESP

Mateus Canniatti Ponchio ${ }^{\Theta}$

School of Adversing and Marketing - ESPM

\begin{abstract}
The purpose of this research is to verify how loyal students are to higher education institutions. According to this research, it was noticed that relationship marketing is critical to create and maintain a relationship between institutions and students, such relationship being developed towards customer retention and loyalty. The survey involved 352 students reading Business Administration at three institutions in the State of São Paulo. Data was analyzed through Multiple Linear Regression Analysis. The results showed that student-customers are prone to being loyal to their higher education institutions. The constructs behind student-customer loyalty are: Perceived Quality, Satisfaction, Emotional Behavior and Trust, responsible for $46 \%$ of data variability. From these results, many academic and management implications were discussed, showing that student-customer loyalty is an important strategic goal to be pursued by such companies.
\end{abstract}

Keywords: Relationship marketing, loyalty, retention, higher education

Received in 07/13/2010; accepted in 03/14/2011; published in 06/19/2012

*Corresponding authors:

$\dot{t}$. Master in Business
Administration, Methodist

University of Piracicaba -

UNIMEP

Affiliation: Professor

Adventist School of Bahia

Address: IAENE, Caixa

Postal 18 Capoeiruçu -

Cachoeira, BA - Brazil.

E-mail:

fvmbergamo@unimep.brP

hone: (75)3425-8000
$\Omega$ Doctor in Educational Administration, UNIMEP.

Affiliation: Professor

Methodist University of

Piracicaba - UNIMEP

Address: Rodovia do

Açúcar km.156,

Piracicaba - SP - Brazil

E-mail:

cgiuliani@unimep.br

Phone: (19) 3124-1515

${ }^{¥}$ Doctor in Business
Administration, University
of São Paulo - USP
Affiliation: Professor
Methodist University of
Piracicaba - UNIMEP
Address: Rua Guaporé
n.461 - Ribeirão Preto -
SP - Brazil
E-mail:
shcamargo.ml@convex.co
m.br
Phone: (16)3622-5691

Phone: (16)3622-5691
+ Doctor in Business Administration , FGV-SP Affiliation: Professor Fundação Getúlio Vargas /EAESP

Address: Rua Itapeva, 474, sala 903, São Paulo - SP

- Brazil.

E-mail:

Felipe@realistacons ultoria.com.br Phone: (11) 3207 6800
$\Theta$ Doctor in Business Administration, FGVEAESP Affiliation: Professor Escola Superior of Propaganda and Marketing - ESPM

Address: Rua Dr. Álvaro Alvim, 123 - Vila Mariana - São Paulo - SP -

Brazil.

E-mail:

mponchio@espm.br Phone: (11) 5085-4500

Editor's note: This paper was accepted by Antonio Lopo Martinez.

\title{
(cc) B'-NC-sA
}

This work is licensed under a Creative Commons Attribution-Noncommercial-Share Alike 3.0 Unported License 


\section{INTRODUCTION}

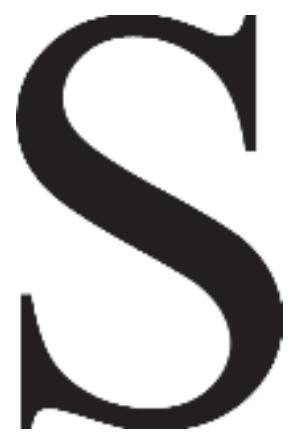

ervice providers have been noticing increased competition within their sectors. Amongst such sectors, Education deserves attention the most. From matured markets, such as America and Europe, to emerging Asian and Latin American markets, it is easy to see the educational sector acting as an economic niche. Czarniawska and Genell (2002) pointed out that education institutions have been changing from government-funded think tanks to self-funded institutions due to increased competition. It has got into people's minds in such way that they have naturally started to perceive education as a market. Commoditization is transforming the nature of this sector, as it is beginning to accept business ethos and its commercial practices.

Such commoditization and increasing competition levels, along with social and economic aspects associated to little enrolment levels and college dropouts, have unveiled the marketing reality in education institutions and also their relationship approach. Looks like it is common sense that understanding the client and keeping a close relationship with them is extremely important in this new world economy. And it is in service providing companies that such marketing relationship approach finds most fertile soil to grow, as, in these companies, there is a stronger personal contact, with emotional attachment, as well as the difficulty, from the customer's point of view, to evaluate a large number of service providers.

The biggest output of a full-fledged relationship marketing is the consumer loyalty concept. The quest for a client's loyalty closely resembles what is sought by education institutions when it comes to a student retention program. Loyalty studies have been contributing to marketing literature for decades, encompassing many different issues and markets. Likewise, theories on what makes a student-customer stay in the institution have been evolving since Tinto's classic work (1975). However, only a few sought to find a intersection between marketing and education approaches, such as Hennig-Thurau, Langer and Hansen's work (2001), which is a relationship quality-based student loyalty (RQSL) model based on the model proposed by Tinto $(1975 ; 1993)$.

Therefore, in order to better understand consumer loyalty issues within higher education market directed to Brazil's reality, the main purpose of this work is to verify how loyal private institution's student-customers are based on Tinto's "Student Integration"(1975; 1993) and Hennig-Thurau, Langer and Hansen's "RQSL” (2001). For 
such, this article is structured as follows: the first part revisits theories in relationship marketing, retention and loyalty. The second part devises loyalty and retention concepts, associating them with the education market. Then, the methodology presents procedures used in field research and, last, the analysis and final considerations regarding researched data.

\section{RELATIONSHIP MARKETING AND CLIENT RETENTION}

The Relationship Marketing concept has been in vogue since the 1980s. In the same year Levitt (1983) used the marriage metaphor to say that "one-night stands are over" and that "marriage is necessary and much more convenient", when analyzing the need of a long-term relationship buyers and sellers, Berry (1983) created and introduced the term "Relationship Marketing" to Academia.

To Hennig-Thurau and Hansen (2000), the Relationship Marketing concept will soon be mature. After an early theory development stage, discussions on the subject have started to dominate marketing debates in both academic and organizational environments (FERNANDES \& PROENÇA, 2005). The emphasis on Relationship Marketing is based on the premise that a company performs better when relationship between buyer and seller are as tight as possible (Anderson, 1995), broadening the traditional marketing concept and creating and maintaining relationships in order to retain clients.

Even though Relationship Marketing still needs its theory to be defined and described more deeply, in practical terms it has become a parameter for modern marketing administration. Meanwhile, the companies' perception must follow this new train of thought. Grönroos (1996) states that the main changes in a company' business philosophy can only be required once Relationship Marketing is truly adopted; otherwise, said company will only be given a supporting role in this new business world reality.

Within this perspective, client retention comes as a critical concept in such approach (Christoper, Payne \& Ballantyne, 1994; Hennig-Thurau, Klee, 1997; Payne \& Frow, 2000). As defined by Jamal (2004), client retention is the company's ability to retain their won customers. Shajahan (2006) defines retention as the company's ability to offer a client not only a buying product, but also a relationship pattern within a specific period. Ahmad and Buttle (2001) state that client retention has been seen as a mirrored image of the company's evading clients, that is, high retention levels mean low company evasion. 
Reichheld and Sasser (1990) identify client retention as the area where most opportunities blossom. Sheth and Parvatiyar (1995) convey client retention as a result of an efficient relationship marketing practice. This is one of the main strategic goals sought by companies and has been acknowledged as a meter to Relationship Marketing's success. What boosts such perception are some studies showing small raises in client retention levels leading to astounding positive effects on companies' profits in many different fields (Reichheld \& Sasser, 1990; Reichheld, 1996). Moreover, Gupta, Lehmann and Stuart (2004) associate retention increase with company market value.

Relationship Marketing and client retention approaches have always been followed by a tendency to focus more on company vision (service providers) than client perspective. It is crucial to know the client's desires and motivations, as well as their inner reasons to keep or to end a relationship, even before measuring the benefits of a retention scenario. Marketing relationships must be seen as dynamic and coming from a human behavior process. Dwyer, Schurr and Oh (1987) were the first marketing thinkers to identify that the relational buying behavior was studied and treated as a minor event, instead of being understood as a larger process, even after the ever growing understanding that relationship is very important. Based on the Social Exchange Theory, the authors explain that buyerseller relationships involve analogous benefits and costs, such as the reduction of uncertainties, exchange dependency and efficiency and social satisfaction.

Amongst the approaches to understand the factors that influence clients in keeping relationships, there is the "Relationship Quality" approach. Proposed by Hennig-Thurau and Klee (1997), it is a varied approach within buyer-seller long-term relationships that focus on client transaction evaluation and their relationship as key to predict relational results, influenced by many constructs. To Crosby, Evans and Cowles (1990), relationship quality, seen through the client's eyes, is accomplished when the sales person has the ability to diminish uncertainties perceived by the client at the time of the purchase. Figure 1 displays the resulting theory model: 


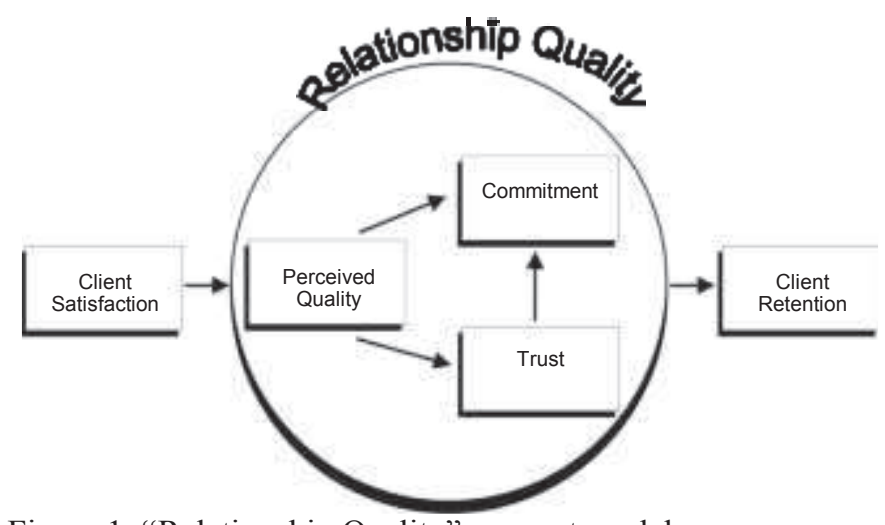

Figure 1: "Relationship Quality" concept model

Source: Hennig-Thurau and Klee (1997)

\section{LOYALTY}

As a complement to the ever growing marketing relational approach, both in theory and in hands-on market management, the client loyalty concept has been playing an essential part in this perspective (Sheth \& Parvatiyar, 1995), motivating the development of a tight relationship, one step further than a mere repetitive behavior. To Too, Souchon and Thirkell (2001), Relationship Marketing efforts increase client loyalty and their positive perception of the relationship. Oliver (1999 p.34) defines loyalty:

\footnotetext{
A deep and secured repurchase behavior commitment and consistent adhesion to a product/service in the future, causing repetitive purchases from the same brand, despite any situational influence and marketing efforts that may cause a change behavior.
}

Thus, loyalty is an element basically developed by what Rowley and Dawes (2000, p.539) call an "interaction between attitude and behavior". Based on this definition, Oliver (1999) points out that client loyalty is an essential factor to develop a buyer-seller relationship. OLIVER's understanding (1999) is confirmed by Jacoby and Knyer (1973), saying that loyalty to a brand is an essentially relational phenomena, and Sheth and Parvatiyar (1995), pointing out that loyalty is a measuring factor of the relationship developed by the client with a company, products and symbols.

The concept of loyalty has been giving a hard time to researchers since it was first conceived. It has been outlined through time, but there are still some gray areas in what client loyalty really means and some doubt regarding the process dynamic that makes a client become loyal to a brand or a company. When Relationship Marketing came, loyalty began to be seen as the main strategic goal to be reached within this approach. The main understanding of the loyalty concept must be of its double personality, based not only in 
behavioral aspects, but also in attitude aspects. The consumer first develops the idea of loyalty intellectually, and then the loyal behavior comes through (DICK \& BASU, 1994; GREMLER \& BROWN, 1998). This thought is aligned to the Rational Action Theory, which indicates that behaviors are preceded by attitudes.

The understanding of loyalty's attitude aspects is extremely important to develop a Relationship Marketing strategy. Attitude loyalty reflects what the consumers feel and think about a certain product or service, which represents an association between an object and an evaluation (DICK \& BASU, 1994). This scenario leads to the perception that loyalty, or a profound emotional attachment between the client and the company, brand or product, cannot be defined only by mere client retention. It cannot be the definite goal within a marketing relational approach, by only focusing on behavioral aspects. Indeed, client retention definitions (Ahmad \& Buttle, 2001; Jamal, 2004; Shajahan, 2006) focus only on keeping clients, without paying attention to more cognitive aspects in this process, what Hennig-Thurau and Hansen (2000) put as a client-company vision, not the opposite. The main focus of each company, when deploying a relationship management strategy, should be, then, to retain clients, but, most of all, to create loyalty (Zineldin, 2006).

Although client loyalty has increased its attractiveness as a company goal, especially in the service sector (Heskett et al., 1994), studies show different approaches to priors that led to its construction. Hennig-Thurau, Gwinner and Gremler (2002) carried out a survey on several studies on client/company long-term relationship success influence factors and found that the success is characterized by how loyal they are and mouth-tomouth reputation. The authors emphasized that "Relationship Quality" constructs and relational benefits are key ingredients to create loyalty, namely:

Satisfaction - to many thinkers, it is a key variable to understand loyalty (Crosby, Evans \& Cowles, 1990; Palmer \& Bejou, 1994; Hennig-Thurau \& Klee, 1997; Garbarino \& Johnson, 1999), shown as an evaluation on the company's performance made by the client after a purchase, against their expectations. Hennig-Thurau and Klee (1997) indicate that satisfaction is a strong loyalty predecessor that also bears influence upon other constructs.

Perceived Quality - Perceived quality, attached to the client expectancy-company performance relationship, is essential to create client loyalty. Hougaard and Bjerre (2003) stress that the service quality perceived by the customers is one of the key elements to Relationship Marketing efficiency while searching for a competitive differential strategy. 
Trust - Also considered essential in terms of client loyalty and relationship, widely associated to its success (Naudé \& Buttle, 2001). Trust can be defined as the credibility and the interest perceived by the client regarding the company, also called "goodness" (Doney \& Canon, 1997), whether it is the company as a whole or only the sales person (Crosby, Evans \& Cowles, 1990; Wong \& Sohal, 2002).

Commitment - Commitment to relationship, also seen as a base construct to a quality relationship. It is considered the most important loyalty construct (Garbarino \& Johnson, 1999; Pritchard, Havitz \& Howard, 1999; Fullerton, 2003). As Pritchard, Havitz and Howard (1999, p.345) put it, when forming loyalty, commitment has a huge "mediating effect". That is, loyalty is only accomplished with client commitment.

Upon the explanation of such influence factors, a basic overview on loyalty within the higher education sector is described below.

\section{LOYALTY AND HIGHER EDUCATION SECTOR}

Milliken (2007) uses a good metaphor to describe the student-customer's low loyalty scenario regarding education: epidemics. This is an epidemic that affects the survival of many education institutions in all levels. Higher education has been living this reality for a long time, but, since the last decades of the 20th century, it has raised more attention, as elements such as globalization and competition have been contributing to its importance. According to Schwartzman (2003), dropping out has become one of the most important issues regarding Higher Education Institution survival. It is now treated as a trend in this sector, along with delinquency, vacant openings and less lower class students.

Thus, there is this relentless need to retain students that are already enrolled. As defined by Berger and Lyon (2005, p.3), retention, in the higher education context, is the "ability of a school or university to successfully graduate students that have enrolled in the institution in the first place.” Kotler and Fox (1994, p.383) cannot stress enough by saying that "retaining enrolled students is as important as luring and enrolling them." In Herzog's opinion (2005, p.923), the student-customer retention approach is "a challenge, both theoretically and in terms of institutional operation". In this background, McLaughlin, Brozovsky and McLaughlin (1998) defend the idea that student retention is a strategic goal, followed by a deep change in the Higher Education Institution's organizational culture, treating student-customers as actually stakeholders. 
Mortenson (2005) calls student retention decisions in institution's persistence. These terms presents a time issue regarding student-customer retention. While planning persistence measurement and, thus, retention, the researcher must answer the following questions: How are students faring the academic path? Who is doing well and who is not? Students are persisting throughout the years? Where their persistence needs to be improved? Information used to answer these questions comes from student enrolment data and their academic performance in defined points in time. This information must obviously be crossed with demographic and geographic data regarding the surveyed students (WETZEL, O’TOOLE \& PETERSON, 1999; MORTENSON, 2005).

To Kotler and Fox (1994, p.385), "concerning the limited number of potential students, big efforts and other recruiting costs, the school must make concentrated efforts to retain students that, with some help, can become successful at the institution." When studying the cost-effectiveness of investment in student retention programs, Simpson (2003) confirmed that institutions that used this tool had return of $450 \%$ to $650 \%$ over costs applied to said programs, showing that this is a feasible and sustainable strategic goal. It is clear that treating retention management as a vision that must encompass the whole High Education Institution (employees, professors, collaborators) shows that higher education is also a service to be provided with quality and competence, focusing on the student as a client who must be satisfied and charmed. The marketing relational approach is, therefore, is an underlying vision (ROWLEY, 2003; SHEIK, 2005).

Student-customer retention is a topic that has been studied under many social perspectives (BRAXTON \& HIRSCHY, 2005; DONOSO \& SCHIEFELBEIN, 2007). By envisioning retention as a tight relationship between the student and their Higher Education Institution, this interaction perspective seems more compatible with Relationship Marketing approach. Undoubtedly, within this perspective, Tinto's $(1975 ; 1993)$ Student Integration Model is the most feasted, applied and, therefore, discussed when it comes to seeking student persistence. Tinto based his studies in an analogy to Durkheim's Suicide theory that, amongst other things, states that suicide is a result of a person's breaking from society due to their inability to become a part of it (BRUNSDEN et al., 2000; DONOSO \& SCHIEFELBEIN, 2007). The "Student Integration Model", thus, is based on the relationship between a student and the institution. Tinto's (1993) revision keeps the model's core aspects and emphasizes interaction issues between process "actors" even 
more: professionals (professors and others directly connected with the student) and classmates.

The "Student Integration Model" is composed of six sets of variables in a causeeffect sequence: Pre-Admission Attributes; Initial Commitment; Academic Integration; Social Integration; Subsequent Commitment; and Results (decision to persist or to quit). According to Tinto $(1975 ; 1993)$, integration takes place in two dimensions: integration with the Institution's academic and social systems. This integration leads to new levels of commitment to the university and to the graduation as a goal. Tinto claims that the interaction between both types of commitment defines if the student will decide to persist or to quit. As the student goes forward in his higher education journey, a few variables shall influence the two commitment dimensions and, later, his/her decision. However, the student is first influenced long before entering the institution, by the Pre-Admission Attributes: the student's Abilities and Attributes, Previous Education and Family Background.

After these initial attributes, the model's next step is the student's established goals. His/her level of commitment to those goals, as well as his/her intention to graduate or not bear influence upon the decision to stay or to quit. When the student begins college life with low expectations to conclude it, he is very prone to dropping out. The student integration's first dimension is the Academic Integration, consisting in structural and normative elements. Structural integration is the bond between the student and the Institution's available structure, in terms of offered and perceived quality. The normative integration is associated to the professional body that is directly connected with the student, e.g. professors. These two visions influence the student's academic achievements and intellectual development, which are determinant in this integration dimension. Increased academic integration leads to increased commitment to goals, intention to graduate and persistence.

The Social Integration dimension is the second step in the model's studentinstitution relationship. It is about the harmony between the student and the institution's social system. There are two approaches to this step: development and how often those positive interactions with other existing students and teachers, supposed there are interaction opportunities, and participation in extracurricular activities inside the institution. When explaining the rest of the model, Tinto states that integration's academic and social dimensions influence the commitment to the institution and to the intention of graduating. External aspects, such as jobs, financial and outside public aspects can also 
bear influence on the student's commitment behavior. In general, it is a combination of both commitments that affect the retention levels of a private higher education institution.

As the association between retention and loyalty is an essential condition to make the company strategy work in a competitive scenario, within a Relationship Marketing context (Zineldin, 2006), it must also be sought by education institutions. Hegelsen and Nesset (2007) establish that, upon this new competitive scenario and taking the present economic system into consideration, it is important that students have bonded with the institution despite any such outside influences.

Thus, when analyzing student loyalty in higher education, the institution must seek long-term goals regarding the student, including the student becoming a recommending agent, leaving a good impression about the institution to the society in general; influencing the institution's service quality with his/her commitment and also coming back to take post-graduation courses (HEGELSEN \& NESSET, 2007). From this conjecture and from consumer loyalty substance, Hennig-Thurau, Langer and Hansen (2001) brought together Tinto's (1993) “Student Integration Model” and Hennig-Thurau e Klee's (1997) Relationship Quality, and created the RQSL model - Relationship Quality-based Student Loyalty. Every construct from "Relationship Quality" model, plus Commitment to Graduation Goals and Cognitive as direct causes of student-customer loyalty. RQSL fitting pieces are the Commitment variables, treated as key-constructs, preceded by the positive influence of the student's Academic and Social Integration, and negative influence of Commitment to Other Activities Not Related to University, such as jobs, family, hobbies, leisure.

This study has considered RQSL variables, plus student satisfaction regarding the institution, as research basis. Figure 2 shows the final model used in this research:

\section{METHODOLOGY}

As for the method, a descriptive quantitative research was carried out through a transversal cut survey (Malhotra, 1999), so as to test the cases. Business Administration students from Campinas, in the State of São Paulo, were used as sample. Choosing only one academic course was justified, as not only the students would have a similar train of thought, but also Business Administration is a good example of the increasing number of higher education institutions. Another thing is that similarities between structural aspects in different institutions can make the research more legitimate. Students from private higher 
education institutions were selected, once the focus in this study is market-oriented Loyalty and Retention.

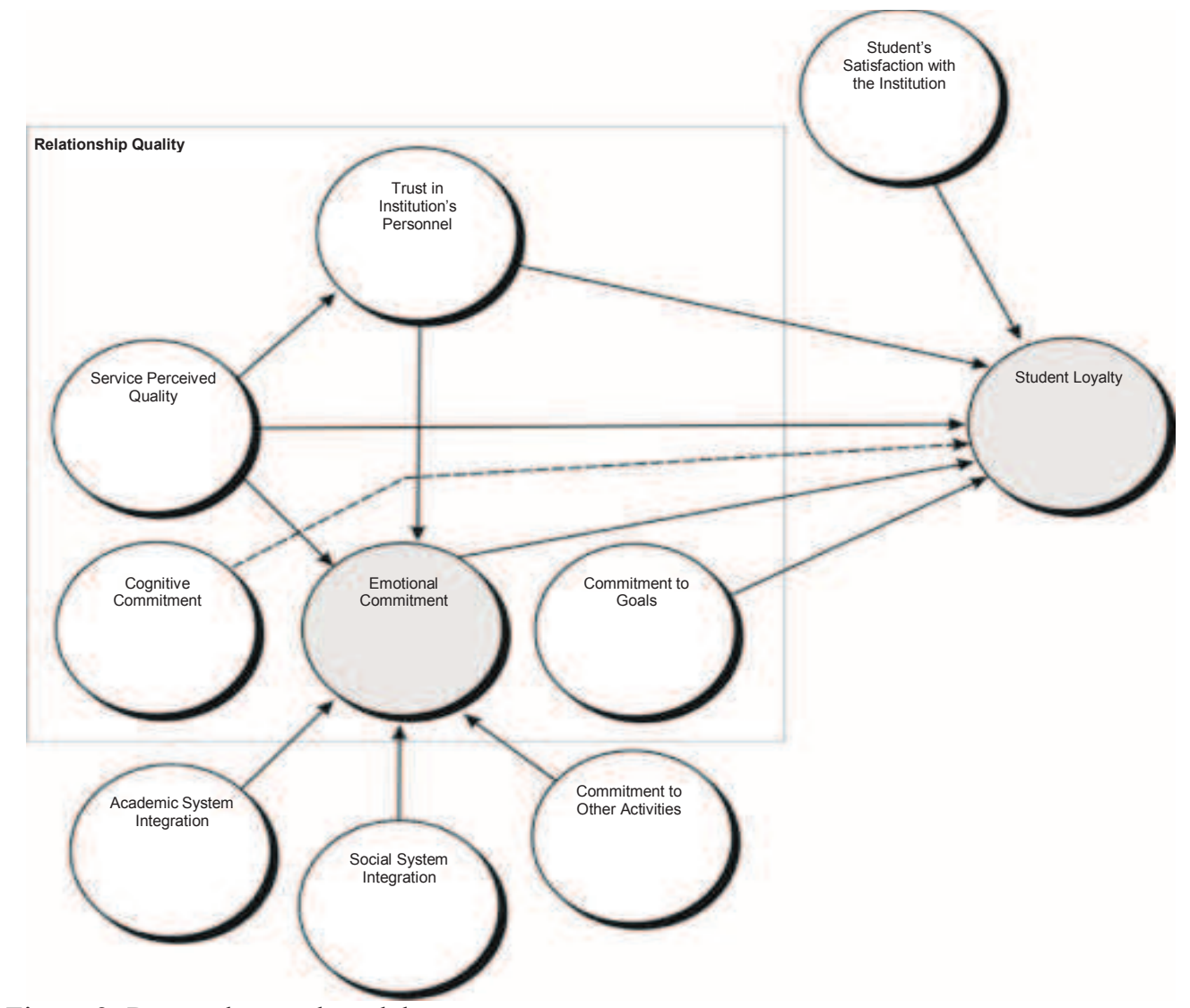

Figure 2: Research-tested model

Source: Adapted from Hennig-Thurau, Langer and Hansen (2001)

The sample was classified as a non-probabilistic (convenient) sample (Malhotra, 1999), from three types of education institutions: University, University Centers and University Schools. The total sample was composed of 352 surveyed students.

The research instrument was a survey questionnaire with 47 items on loyalty and construct analysis, as proposed by the model. According to the research goals, the model variables were classified as dependent and independent, namely: a) satisfaction, perceived quality, social integration, academic integration and cognitive commitment to goals, to other activities and independent variables; b) loyalty, trust and emotional commitment, as dependent variables. Alternatives were arranged in a Likert format, in which the interviewed marked how much they agreed or disagreed with each of the affirmatives presented, using a five-point scale, from (1) "totally disagree" to (5) totally agree. The third part was arranged in the same type of scale, based on Tinto's (1993) "Student Integration Model", such as Commitment to graduating, Academic Integration, Social Integration, Commitment to Job, Commitment to Family and Commitment to Unrelated 
Activities. It is important to use this type of scale to measure their attitude, which can vary from extremely positive to extremely negative (MALHOTRA, 1999).

Statistical procedures to be used in field-gathered data were developed with the help of SPSS ${ }^{\mathrm{TM}}$ software, version 16.0. Firstly, the interviewees were analyzed through descriptive and exploratory statistics of gathered data, separated by categories using average calculation and standard deviation. This analysis is useful to briefly verify data, visualized in graphics and tables. The statistics technique used to evaluate the proposition was the Multiple Linear Regression Analysis. This technique was used due to its powerful effect and flexibility of relationship between a dependent metric variable and one or more independent variables (Hair, Bush \& Ortinau, 2003).

\section{DATA ANALYSIS}

Firstly, data's descriptive statistics was verified, as shown in table 1.

TABLE 1 - DESCRIPTIVE DATA ANALYSIS

\begin{tabular}{|c|c|c|c|c|c|c|c|}
\hline & University & Age & Gender & $\begin{array}{l}\text { Marital } \\
\text { Status }\end{array}$ & Kids? & Race & $\begin{array}{l}\text { Monthly } \\
\text { Income }\end{array}$ \\
\hline Valid & 352 & 352 & 352 & 352 & 352 & 352 & 352 \\
\hline Average & 1.80 & 23.26 & 1.46 & 1.80 & 1.87 & 1.66 & 2.90 \\
\hline $\begin{array}{l}\text { Standard } \\
\text { Deviation }\end{array}$ & 0.658 & 4.646 & 0.499 & 0.404 & 0.334 & 1.049 & 1.318 \\
\hline Variance & 0.433 & 21.581 & 0.249 & 0.163 & 0.112 & 1.101 & 1.737 \\
\hline
\end{tabular}

Source: Field Research

When investigating how reliable multidimensional constructs are, the scales' internal consistency needs to be verified. Cronbach's Alpha (Malhotra, 1999) was used as a tool, and the outcome was that the data gathering instrument used in this research, with 47 items, reached a 0.909 Cronbach's Alpha coefficient, indicating a high level of reliability.

In the first phase of the multiple regression analysis, the relationship between the dependent variable "Emotional Commitment" and "Academic Integration", "Social Integration", "Commitment to Other Activities" variables are checked, besides Perceived Quality" and "Trust". Correlations pointed to a linear relationship. In the surveyed group, the "Emotional Commitment" variation is linearly associated with the presented predictive dimensions, relating 69.4\%. Table 2 shows Multiple Regression model coefficients for the "Emotional Commitment" variable. 
TABLE 2 - MULTIPLE REGRESSION MODEL SUMMARY - EMOTIONAL COMM.

\begin{tabular}{c|c|c|c|}
\hline $\mathbf{R}$ & $\mathbf{R}^{\mathbf{2}}$ & Adjusted R & Standard Error $^{\mathbf{2}}$ \\
\hline $0,694^{\mathrm{a}}$ & 0,482 & 0,474 & 2,46042 \\
\hline
\end{tabular}

aredictive Variables: Quality, Trust, Comm. to Other Activities, Academic Integration, Social Integration Source: Field Research

The analysis of variance (ANOVA) presented in table 3 leads to the conclusion that it is possible that the adjusted model can be used to describe the relationship between variables. 0.000 significance means $\mathrm{H}_{0}$ is excluded (variables bear no relation to each other), so at least one of the predictive variables is associated with "Emotional Commitment", therefore, regressing.

TABLE 3 - ANOVA OF REGRESSION ADJUSTMENT - EMOTIONAL COMPONENT

\begin{tabular}{l|c|c|c|c|c}
\multicolumn{1}{|c}{ Model } & $\begin{array}{c}\text { Sum of Square } \\
\text { Number }\end{array}$ & $\begin{array}{c}\text { Degrees of } \\
\text { Freedom }\end{array}$ & $\begin{array}{c}\text { Square } \\
\text { Number } \\
\text { Means }\end{array}$ & F Statistics & Significance \\
\hline Regression & 1948.527 & 5 & 389.705 & 64.375 & $0.000^{\mathrm{a}}$ \\
\hline Residue & 2094.564 & 346 & 6.054 & & \\
\hline Total & 4043.091 & 351 & & & \\
\hline
\end{tabular}

aredictive: (Constant), Quality, Trust compose Other Activities, Academic Integration, Social Integration Source: Field Research

In conclusion, taking the whole interviewee group into consideration, the Emotional Commitment is positively influenced by the student's Integration in the institution's Academic System. This scenario reflects strongly when the student's integration in the Institution's Social System is taken into consideration. On the other hand, there is a negative influence on commitment regarding the Institution due to other activities performed by students, such as hobbies, entertainment, family and work.

Upon the first analysis, the main multiple regression of this research was made. According to the theory reference, Student-Customer Loyalty is positively influenced by Satisfaction, Trust, Perceived Quality, Cognitive Commitment, Emotional Commitment and Commitment to Goals. Under this model, 68\% of Loyalty variation comes from predictive dimension variation mentioned in the RQSL model. Such association was justified upon examination of the multiple determination coefficient $\left(\mathrm{R}^{2}\right)$, resulting from the regression analysis. Around $46 \%$ of Loyalty variations express the cause-effect relationship with predictive factors. The standard error shows that the interviewed students have an even perception tendency.

\begin{tabular}{c|c|c|c|}
\hline TABLE 4 - MULTIPLE REGRESSION MODEL SUMMARY - STUDENT LOYALTY \\
\hline $\mathbf{R}$ & $\mathbf{R}^{\mathbf{2}}$ & \multicolumn{1}{|c|}{ Adjusted R } & \multicolumn{1}{c|}{ Standard Error } \\
\hline 0,680 & 0,463 & 0,454 & 3,43831 \\
\hline
\end{tabular}

Source: Field Search 
The residual analysis shows that the sum of the square numbers of the residue is a bit higher than regression, which leads to the conclusion that there is a dispersion. 0.000 significance makes F statistics confirm $\mathrm{R}^{2}$. Table 5 below shows the regression's ANOVA.

TABLE 5 - ANOVA OF REGRESSION ADJUSTMENT - STUDENT-CUSTOMER LOYALTY

\begin{tabular}{c|c|c|c|c|c}
\hline \multicolumn{2}{c}{ Model } & $\begin{array}{c}\text { Sum of } \\
\text { Square } \\
\text { Number }\end{array}$ & $\begin{array}{c}\text { Degrees of } \\
\text { Freedom }\end{array}$ & $\begin{array}{c}\text { Square } \\
\text { Number } \\
\text { Means }\end{array}$ & \multicolumn{2}{c}{ F Statistics } & Significance \\
Regression & 3514.871 & 6 & 585.812 & 49.553 & 0.000 \\
\hline Residue & 4078.572 & 345 & 11.822 & & \\
\hline Total & 7593.443 & 351 & & & \\
\hline
\end{tabular}

Source: Field Research

Figure 3 shows the model's final results, including all researched and analyzed variables:

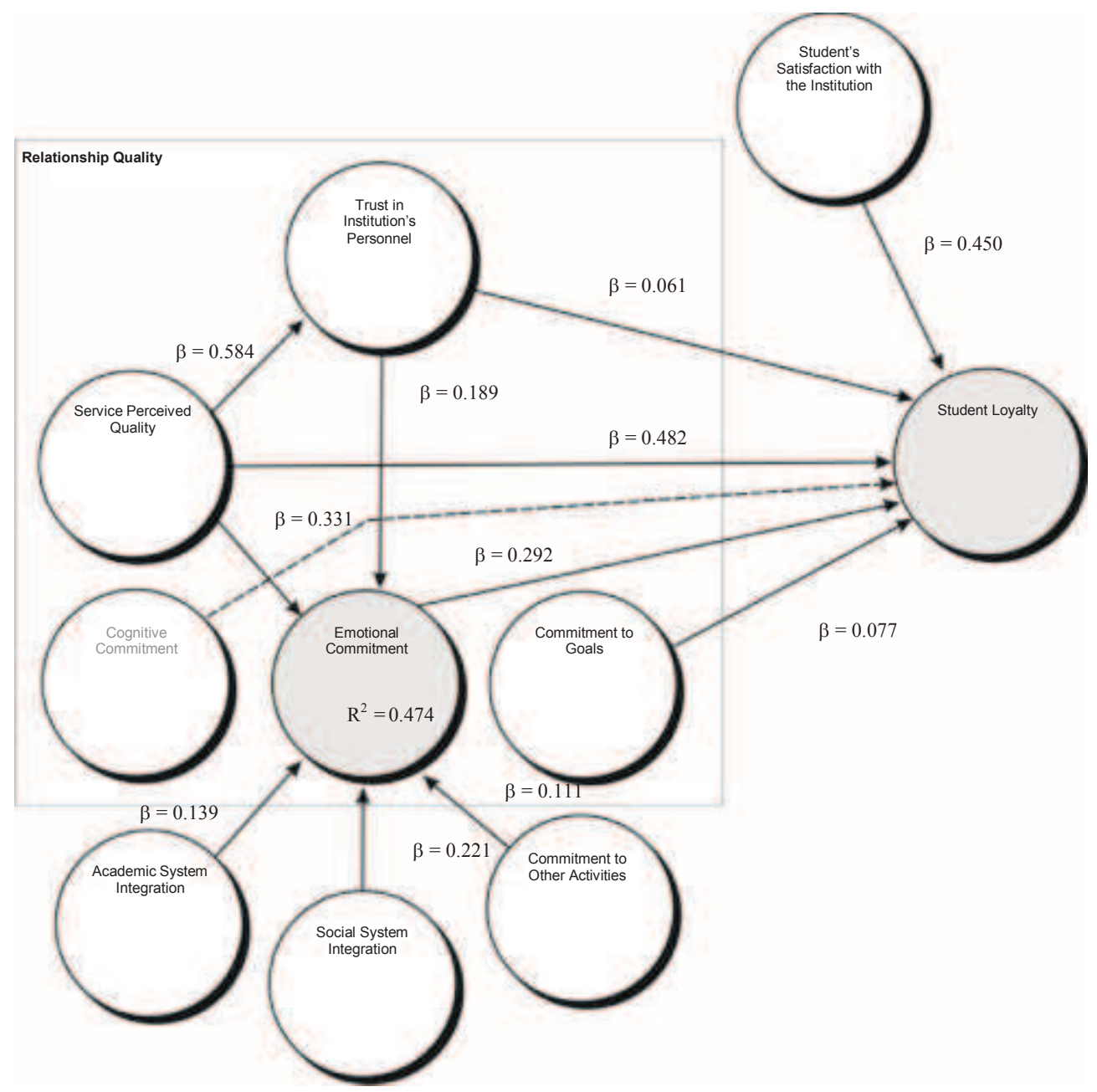

Figure 3 - Estimated coefficients - Student Loyalty and its relationship with other variables Source: Prepared by the Author 


\section{CONCLUSION AND IMPLICATIONS}

Most relationships proposed by the models are adequate for the surveyed sample, confirming the existence of a tendency of loyalty by student-customers. This leads to an analysis on the research results. The multiple linear regression analyses conducted for "Trust", "Emotional Commitment" and "Loyalty" dependent variables presented the following results. First, it is easy to see the usefulness of the research and its questionnaire to better understand the importance of loyalty constructs for higher education services. Student-customer loyalty comes from many factors, and their perception of such factors is positive to their developing a full relationship with the Institution. Results showed that $46 \%$ of loyalty can be explained by the influence of its relationship with proposed predecessors, that is: Perceived Quality, Satisfaction, Emotional Commitment and Trust. The interviewed students were inclined towards a loyalty status, showing it can be accomplished if the Institution acts on the constructs presented as predecessors.

Thus, in a loyalty perspective, the research proved that the most powerful variable is perceived quality of the institution services by the student-customers. Such variable also bear reasonable influence on many other loyalty predecessor variables, such as trust and emotional commitment. It is important to stress that quality cannot be indicated only by standards and references, but also by the students' perception of what is important in terms of quality to them. The institution must attempt to increase the student-customers' perceived quality in its tangible and intangible aspects.

The second most powerful variable regarding loyalty is satisfaction. Not only in higher education, but in several company sectors, satisfaction is a first step into keeping a relationship. In private institutions, as the ones in this research, satisfaction cannot be overlooked. The third most powerful variable is the Emotional Commitment, which was positively influenced by the student-customer's integration into the academic system's activities and personnel and also in the social system. The negative influence was detected in the student-customer's commitment to other activities, such as leisure, family and work. In this multiple regression analysis, $47 \%$ of the Interviewees' Emotional Commitment came from the relationship with those variables. The Trust variable was also positive regarding student-customer loyalty. The importance of trust is increased by its positive influence not only on loyalty, but also on the student-customer's emotional commitment.

From the research results, one can conclude that the student-customer tends to be loyal to higher education institutions. From this point of view, then, it is important to 
understand that there are attributes that influence the decision to persist that must be observed, which are, ranked in terms of importance, perceived quality, satisfaction, emotional commitment and trust.

The results and the development process in this study, whether regarding theory or methodology, help the development of marketing research applied to private higher education. As in many industries, the role of Hennig-Thurau e Klee's (1997) "Relationship Quality" model variables have positive impact on student-customer loyalty. It is clear that such variables are important in any such study that aims at discussing student-customer persistence in a chosen higher education institution.

It is recommended that institution managers seek to look at student-customer loyalty as a strategic marketing goal. Loyalty is an attitude state in which the clients feel connected to an organization, not only recommending and defending them, but also refusing to drop out. The theory reference presented the benefits of loyal customers, not only in short and mid-term plans (financial), but also in the long run (retained clients).

Within loyalty influencing factors, perceived quality was proved the most powerful variable. However, it is recommended that institution managers do not limit themselves to seeking quality through indicators such as ENADE and internal institutional evaluations. Perceived quality contemplates perception from the student's point of view, which is often overlooked by managers. Physical and human aspects, as well as intangible aspects (syllabus, evaluation methods and penetration in the job market), must be devised in this concept.

Another relevant aspect is satisfaction. Due to the Disconfirmation Paradigm, it would be interesting if the managers knew what the students expect from the institution, knowing their expectations. The third most powerful variable is the emotional commitment, implying some relevant actions, such as the emotional attachment, pride in the institution, social integration (get-togethers, social events and informal student groups) and academic integration (research groups, applied groups, academic events, extracurricular activities and approachable teachers).

Trust also influences loyalty. Trust can be an important benefit for the studentcustomer and their relationship with the institution. Regardless of the segment, it is essential that managers maximize students' trust in the institution's personnel and processes. In the base model of this research, trust influenced perceived quality and emotional commitment strongly. Therefore, it is a limiting construct within the model and 
should not be overlooked. A recommendation to the Institutions is the constant training of employees that deal with the students directly, so they can exert trustworthiness, benevolence and hospitality.

The purpose of this essay was to verify how prone to loyalty students of private higher education institutions are. In order to develop such literature and to bolster the topic's theory reference, new study opportunities arise from suggestions made regarding limitations of this research. We suggest new research is conducted for other realities or vertically. As employees, especially those who deal directly with student-customers, were proved to be critical in developing loyalty-related points, such as perceived quality, trust and satisfaction, we suggest a study on the these people's perception of their role within a strategic policy to maintain relationships. Another study would be seeking more understanding of this role regarding the constructs that form the student-customer's loyalty to an institution.

\section{REFERENCES}

AHMAD, R.; BUTTLE, F. Customer retention: a potentially potent marketing management strategy. Journal of Strategic Marketing, 9(1), p. 29-45, Mar. 2001.

ANDERSON, J. C. Relationship in business markets: exchange episode, value creation and their empirical assessment. Journal of the Academy of Marketing Science, 23(4), p. 346$350,1995$.

BERGER, J. B.; LYON, S. C. Past to present: a historic look at retention. In: SEIDMAN, Alan (Ed.). College student retention: formula for student success. Westport: Greenwood Publishing Group, 2005.

BERRY, L. L. Relationship marketing. In: BERRY, L. L.; SHOSTACK, L. \& UPAH, G. (Ed.). Emerging perspectives on services marketing. Chicago: American Marketing Association, 1983.

BRAXTON, J. M.; HIRSCHY, A. S. Theoretical developments in the study of college student departure. In: SEIDMAN, Alan (Ed.). College student retention: formula for student success. Westport: Greenwood Publishing Group, 2005.

BRUNSDEN, V. et al. Why do HE students drop out? A test of Tinto's model. Journal of Further and Higher Education, 24(3), p. 301-310, 2000.

CHRISTOPHER, M.; PAYNE, A.; BALLANTYNE, D. Marketing relacional: integrando la calidad, el servicio al cliente y el marketing. Madrid: Ediciones Diaz de Santos, 1994.

CROSBY, L. A.; EVANS, K. R.; COWLES, D. Relationship quality in services selling: an interpersonal influence perspective. Journal of Marketing, 54(3), 68-81, p. 1990. 
CZARNIAWSKA, B.; GENELL, K. Gone shopping? universities on their way to market. Scandinavian Journal of Management, 18(4), p. 455-474, Dec. 2002.

DICK, A. S.; BASU, K. Customer loyalty: toward an integrated conceptual framework. Journal of the Academy of Marketing Society, 22(2), p. 99-113, 1994.

DONEY, P. \& CANNON, J. P. An examination of the nature of trust in buyer-seller relationships. Journal of Marketing, 61(2), p. 35-51, 1997.

DONOSO, S.; SCHIEFELBEIN, E. Analisis de los modelos explicativos de retención de estudiantes en la universidad: uma visión desde la desigualdad social. Estudios Pedagógicos, 33(1), p. 7-27, 2007.

DWYER, F. R.; SCHURR, P. H. ; OH, S. Developing buyer-seller relationships. Journal of Marketing, 51(2), p.11-27, 1987.

FERNANDES, T. M.; PROENÇA, J. F. Relationships and relationship marketing: an interdisciplinary perspective. In: INDUSTRIAL MARKETING PURCHASING CONFERENCE, 21, 2005, Rotterdam, Netherlands. Proceedings... Rotterdam: IMP Group, 2005.

FULLERTON, G. When does commitment lead to loyalty? Journal of Service Research, 45(4), p. 333-344, 2003.

GARBARINO, E. ; JOHNSON, M. S. The different roles of satisfaction, trust, and commitment in customer relationships. Journal of Marketing, 63(2), p. 70-87, 1999.

GREMLER, D. D. \& BROWN, S. W. Service loyalty: antecedents, components and outcomes. In: AMERICAN MARKETING ASSOCIATION CONFERENCE, 1998. Proceedings... Chicago: AMA, 1998. p. 9

GRÖNROOS, C. Keynote paper From marketing mix to relationship marketing: towards a paradigm shift in marketing. Management Decision, 35(4), p. 322-339, 1997.

GUPTA, S.; LEHMANN, D. \& STUART, J. A. Valuing customers. Journal of Marketing Research, 41(1), p. 7-18, 2004.

HAIR, J. H.; BUSH, R. P. ; ORTINAU, D. J. Marketing Research. 2. ed. New York: McGraw-Hill, Irwin, 2003.

HEGELSEN, O. ; NESSET, E. What accounts for student's loyalty? some fields study evidence. International Journal of Educational Management, 21(2), p. 126-143, 2007.

HENNIG-THURAU, T.; GWINNER, K. P.; GREMLER, D. D. Understanding relationship marketing outcomes: an integration of relational benefits and relationship quality. Journal of Service Research, 4(3), p. 230-247, 2002. 
HENNIG-THURAU, T.; HANSEN, U. Relationship marketing: some reflections on the state-of-the-art of the relational concept. In: HENNIG-THURAU, T. \& HANSEN, U. (Ed.). Relationship Marketing: gaining competitive advantage through customer satisfaction and customer retention. Berlin: Springer, 2000.

HENNIG-THURAU, T. ; KLEE, A. The impact of customer satisfaction and relationship quality on customer retention: a critical reassessment and model development. Psychology \& Marketing, 14(8), p. 737-764, 1997.

HENNIG-THURAU, T.; LANGER, M. F. ; HANSEN, U. Modeling and managing student loyalty: an approach based on the concept of relationship quality. Journal of Service Research, 3(4), p. 331-344, 2001.

HERZOG, S. Measuring determinants of student returns vs. dropout/stopout vs. transfer: a first-to-second year analysis of new freshman. Research in Higher Education, 46(8), p. 883-928, 2005.

HESKETT, J. L. et al. Putting the service-profit chain to work. Harvard Business Review, 72(2), p. 164-174, 1994.

HOUGAARD, S.; BJERRE, M. Strategic Relationship Marketing. Berlin: Springer, 2003.

JACOBY, J. \& KYNER, D. B. Brand loyalty vs. Repeat purchase behavior. Journal of Marketing Research, 10(1), p.1-9, 1973.

JAMAL, Z. Customer fit and customer retention at an internet recommendation site. In: MARKETING SCIENCE CONFERENCE， ，2004, Rotterdam. Proceedings... Rotterdam: Erasmus University, 2004. Paper.

KOTLER, P. \& FOX, K. F. A. Marketing estratégico para instituições educacionais. São Paulo: Atlas, 1994.

LEVITT, T. After the sale is over. Harvard Business Review, 60, p. 87-93, 1983.

MALHOTRA, N. K. Marketing Research: an applied orientation. 3. ed. Upper Saddle River: Prentice-Hall, 1999.

MCLAUGHLIN, G. W.; BROZOVSKY, P. V. \& MCLAUGHLIN, J. S. Changing perspectives on student retention: a role for institutional research. Research in Higher Education, 39(1), p.1-17, 1998.

MILLIKEN, B. The last dropout: stop the epidemic! Carlsbad: Hay House, 2007.

MORTENSON, T. G. Measurements of persistence. In: SEIDMAN, A. (Ed.). College student retention: formula for student success. Westport: Greenwood Publishing Group, 2005. 
NAUDÉ, P. \& BUTTLE, F. Assessing relationship quality. In: FORD, David. (Ed.) Understanding Business Marketing and Purchasing. 3. ed. Florence: Cengage Learning, 2001.

OLIVER, R. L. Whence consumer loyalty? Journal of Marketing, 63, p. 33-44, 1999.

PALMER, A. \& BEJOU, D. Buyer-seller relationships: a conceptual model and empirical investigation. Journal of Marketing Management, 10(6), p. 495-512, 1994.

PAYNE, A. \& FROW, P. A strategic framework for customer relationship management. Journal of Marketing, 69(4), p. 167-176, 2005.

PRITCHARD, M. P.; HAVITZ, M. E.; HOWARD, D. R. Analyzing the commitmentloyalty link in service contexts. Journal of the Academy of Marketing Science, 27(3), p. 333-348, 1999.

REICHHELD, F. F. A estratégia da lealdade: a força invisível que mantém clientes e funcionários e sustenta crescimento, lucro e valor. Rio de Janeiro: Campus, 1996.

REICHHELD, F. F. \& SASSER, E. Zero defections: quality comes to services. Harvard Business Review, 68(5), p. 105-111, 1990.

ROWLEY, J. Retention: rethoric or realistic agendas for the future of higher education. The International Journal of Educational Management, 17(6), p. 248-253, 2003.

ROWLEY, J.; DAWES, J. Disloyalty: a closer look at non-loyals. Journal of Consumer Marketing, 17(6), p. 538-547, 2000.

SCHWARTZMAN, J. O financiamento das instituições de ensino superior no Brasil. Paper. Instituto de Estudos Avançados, Universidade de São Paulo, 2003.

SHAJAHAN, S. Relationship marketing: texts and cases. New Delhi: Tata McGraw-Hill, 2006.

SHEIK, N. Marketing distance learning programs and courses: a relationship marketing strategies. Online Journal of Distance Learning Administration, 8(2), p.1-7, 2005.

SHETH, J. N.; PARVATIYAR, A. The evolution of relationship marketing. International Business Review, 4(4), p.397-418, 1995.

SIMPSON, O. The costs and benefits of student retention for students, institutions and governments. Studies in Learning, Education, Innovation and Development, 2(3), p. 34-43, 2005.

TINTO, V. Dropout from higher education: a theoretical synthesis of recent research. Review of Educational Research, 45(1), p. 89-125, Winter 1975.

Leaving college: rethinking the causes and cures of student attrition. 2 ed.

Chicago: University of Chicago Press, 1993. 
TOO, L. H. Y.; SOUCHON, A. L.; THIRKELL, P. C. Relationship marketing and customer loyalty in a retail setting: a dyadic exploration. Journal of Marketing Management, 17(4), p. 287-319, 2001.

WETZEL, J. N.; O'TOOLE, D. \& PETERSON, S. Factors affecting student retention probabilities: a case study. Journal of Economics and Finance, 23(1), p. 45-55, 1999.

WONG, A.; SOHAl, A. An examination of the relationship between trust, commitment and relationship quality. International Journal of Retail \& Distribution Management, 30(1), p. 34-50, 2002.

ZINELDIN, M. The royalty of loyalty: CRM, quality and retention. Journal of Consumer Marketing, 23(7), p. 430-437, 2006. 